\title{
Some Characteristics of Photosynthesis of Fresh Water Phytoplankton
}

\author{
by Shun-ei IchImura* and Yusho ArugA**

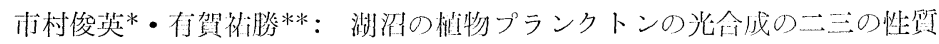

Received May 22, 1958

The photosynthetic activity related with the environmental factors makes the indispensable background for the analysis of primary production of the ecosystem. In the ecological study of organic matter production in lakes, it requires the information on such characteristics of natural phytoplankton. Several excellent studies have been done on these problems, but so far not enough data seem to be collected to elucidate thoroughly many problems still remaining. As noted by many investigators, the photosynthesis of natural phytoplankton differs in seasons and in waters as well. From field survey alone, it is very difficult to make any confirmation of what sort of factor is most essential for photosynthesis as the limiting factor, or how each factor can affect the primary production. Therefore, in order to get quantitative information on the photosynthetic characteristics of natural phytoplankton, it is rather desirable to investigate the photosynthesis under controlled conditions in a laboratory, and the present study was pursued on this line.

\section{Methods}

Methods used in the present study were similar to the one described previously (Ichimura \& Saijō 1958). As for the materials raw waters containing phytoplankton were collected from several lakes in prefectures neighbouring Tokyo. The photosynthesis was measured under laboratory conditions, using $\mathrm{O}_{2^{-}}$, and ${ }^{14} \mathrm{C}$ - method. The amount of phytoplankton was estimated by that of chlorophyll.

\section{The relation of photosynthesis to light intensity}

Lake waters used in this experiment were sampled from the surface of three eutrophic lakes, Kasumigaura. Teganuma and Jōnuma, where dominant phytoplankters growing densely in a gregarious state were Microcystis sp., Fragilaria sp., and Chlamydomonas sp., respectively. Differences in the amount of nutrient materials in each sample were scarcely found. Some of chemical elements were as follows: $\mathrm{NH}_{4}-\mathrm{N}$ was $0.1-0.3 \mathrm{mg} . / 1 ., \mathrm{PO}_{4}-\mathrm{P} \quad 0.05-0.08 \mathrm{mg} . / 1$., and total carbon $40-50 \mathrm{mg} . / 1$. Sample

* Botanical Institute, Faculty of Science, Tokyo University of Education, Otsuka, Tokyo, Japan. 東京教育大学理学部植物学教室

** Biological Institute, The Osaka University of the Liberal Arts and Education, Tennoji, Osaka, Japan. 大这学芸大学生物学教空 
waters filled in $100 \mathrm{ml}$. clear glass bottles were illuminated at various light intensities with a $500 \mathrm{~W}$ flood lamp in a water bath at $20^{\circ}$ for 3 hours.

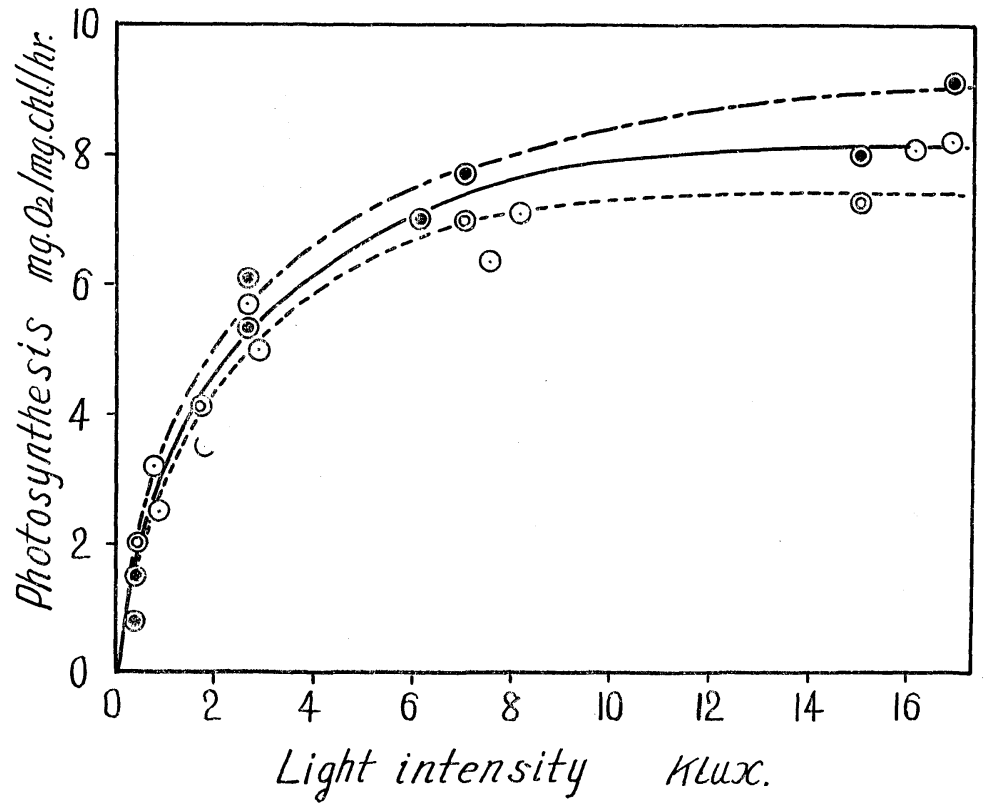

Fig. 1. Relation between photosynthetic rate and light intensity obtained with phytoplankton growing in waters taken from several eutrophic lakes.

-- --, Microcystis in Lake Kasumigaura, - - Chlamydomonas in Lake Jônuma, -(O)-, Fragilaria in Lake Teganuma.
Results of the experiment are shown in Fig. 1. From the feature of photosynthetic curves it may be said that the light saturation of photosynthesis somewhat differs with kinds of phytoplankters used. Namely, the light saturation occurred at about 15 klux. in Microcystis of Kasumigaura, and at about 10 klux. in Chlamydomonas of Jōnuma. However, that in Fragilaria of Teganuma was recorded 7 klux., a little lower than those obtained with two former samples.

The light saturation of photosynthesis was observed at low light intensity in the sample taken from the bottom of trophogenous layer. This is clearly seen in Fig. 2. The samples taken from various depths in Lake Kasumigaura in November included mainly Microcystis sp. The samples from the surface, and 2 and 3 metre depths showed nearly similar

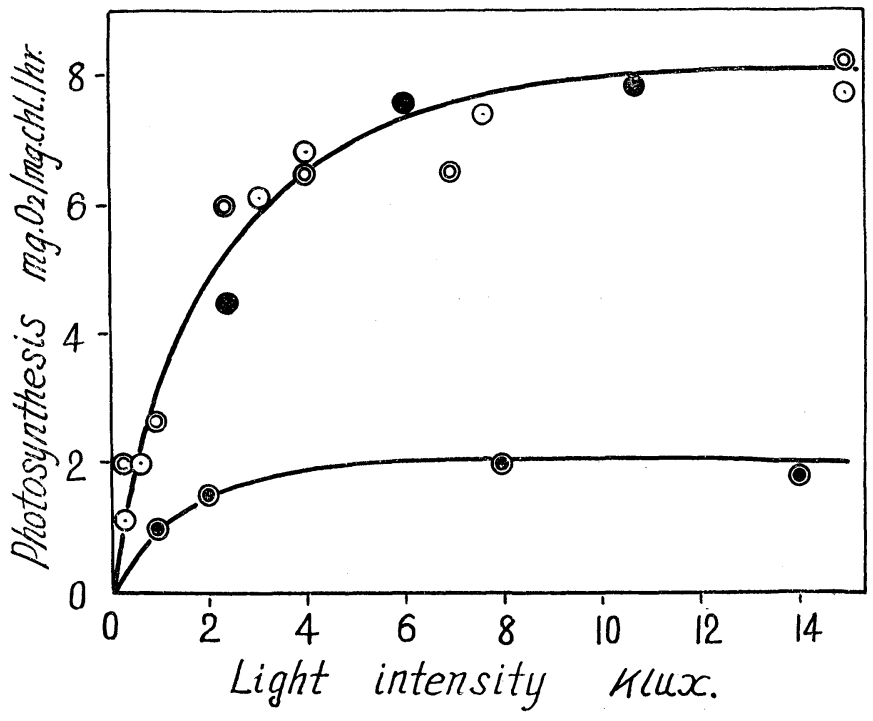

Fig. 2. Relation between photosynthetic rate and light intensity measured in phytoplankton taken from various depth (@) surface, (0) $2 \mathrm{~m},-3 \mathrm{~m},-\bigcirc-4 \mathrm{~m}$ ) of Lake Kasumigaura. 
reaction to light intensity with saturation at ca. $15 \mathrm{klux}$. From this result it may be concluded that the phytoplankton distributed in the trophogenous layer has the same photosynthetic activity, but the plankton living at the layer below the compensation depth has excessively low activity.

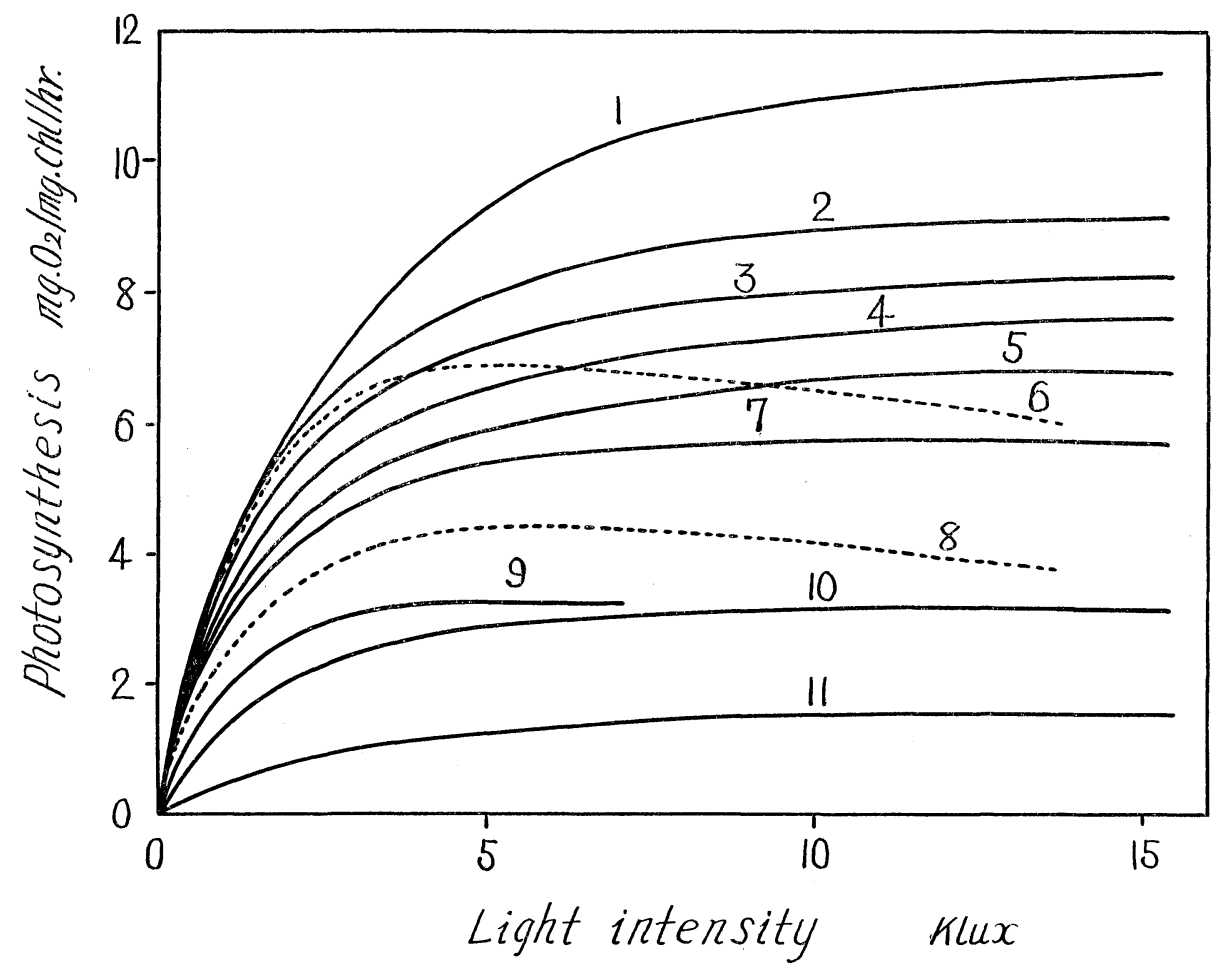

Fig. 3. Maximal photosynthetic activity of natural phytoplankton contained in raw waters taken from various waters.

1. Chlorella suspension, 2. Kasumigaura, 3. Jōnuma, 4. Nakanuma,

5. Teganuma, 6. Tokyo Bay, 7. Harunako, 8. Shimoda Bay,

9. Yamanakako, 10. Shōjiko, 11. Ashinoko.

Phytoplankton collected from oligo- and mesotrophic lakes also showed the similar tendency in photosynthesis in relation to light intensity. However, the photosynthesis of these samples was, even of the surface water, already saturated with about 4 klux. light, and its maximum was strikingly lower than those of eutrophic lakes. For the low photosynthetic activity, in general, the deterioration of phytoplankton in deeper layer seems to be responsible in the above mentioned case, and the deficiency of nutrient salts does in oligotrophic lakes.

\section{Photosynthetic rate of phytoplankton in various waters}

The data of the photosynthetic rate of phytoplankton in natural water are very important in order to compare the primary production in lake with each other. In the previous paper (Ichimura 1958) the photosynthetic rate obtained under field condition 
showed large divergency in each lake. In that experiment the accurate determination of light factor was too difficult to elucidate the relationship between photosynthesis and light intensity exactly. In this experiment, therefore, the photosynthetic rate was investigated under varying light conditions in a laboratory at constant temperature of $20^{\circ}$, and the nutrient conditions remained as they were. Sample waters taken from some eutrophic and oligotrophic lakes, the fundamental distinction of which had been disclosed by Yoshimura (1937) on the basis of nutrient materials in water. As

Table 1. Photosynthetic rate of phytoplankton in various waters, measured by ${ }^{14} \mathrm{C}$ method.

\begin{tabular}{|c|c|c|}
\hline Waters & Date & $\begin{array}{c}\text { Photosynthesis } \\
\mathrm{O}_{2} \mathrm{mg} . / \mathrm{ch} 1 . \mathrm{mg} . / \mathrm{hr}\end{array}$ \\
\hline Kasumigaura & May 16,1957 & 9.1 \\
\hline Jönuma & Oct. 29,1956 & 8.2 \\
\hline Nakanuma & April 24, 1957 & 7.6 \\
\hline Teganuma & May 29, 1956 & 6.8 \\
\hline Harunako & Oct. 29,1956 & 5.7 \\
\hline Kawaguchiko & June 28, 1956 & 4.6 \\
\hline Yamanakako & June 28,1956 & 3.2 \\
\hline Shojiko & June 24,1956 & 3.1 \\
\hline Ashinoko & May 23, 1958 & 1.4 \\
\hline Tokyo Bay & Mar. 20, 1956 & 6.8 \\
\hline Shimoda Bay & June 12,1957 & 4.5 \\
\hline Kuroshio Area & May 2,1958 & $2.0-1.5$ \\
\hline
\end{tabular}

compared with these waters, Chlorella suspension in Detmer's solution, and sea waters were used.

The representative photosynthetic curves selected from the data obtained throughout the year are summarized in Table 1. The maximum photosynthetic rate of phytoplankton is, in general, in eutrophic water about $8 \mathrm{mg} . \mathrm{O}_{2} / \mathrm{mg}$. chl./hr. and in oligotrophic water about $2-4 \mathrm{mg} . \mathrm{O}_{2} / \mathrm{mg}$. chl./hr. The curves, however, varied conspicuously according to the differences of water or of seasons. Such differences may be the result of the variation of nutrient concentration in water, and in some cases they may be atributable to the deterioration of phytoplankton itself. Details on this phenomenon will be discussed in the next paragraph relating to the effect of nutrient salts on photosynthesis.

\section{Effect of nutrient salts on photosynthesis}

The manipulation used in this experiment was similar to that reported by Edmondson (1947) as a whole. After two days keeping of sample waters of 201 . added with various amount of $\mathrm{Ca}\left(\mathrm{NO}_{3}\right)_{2}$ and $\mathrm{KH}_{2} \mathrm{PO}_{4}$, in a growth chamber, with $110 \mathrm{klux}$. illumination at $20^{\circ}$, the sample waters were filled in clear and dark bottles and set out in a water bath at $20^{\circ}$ in order to measure photosynthesis under varying light intensities. The effect of supply of nutrient salts on photosynthesis was exceedingly varied with the amount of those existing in the initial raw water.

Fig. 4 shows the results obtained with the surface water taken from extremely eutrophicated Lake Jönuma in autumn, where the nutrient concentration was more than $0.2 \mathrm{mg}$./l. of $\mathrm{NH}_{4}-\mathrm{N}$ and $0.08 \mathrm{mg}$./1. of $\mathrm{PO}_{4}-\mathrm{P}$ (these analyses were carried out by 
Dr. N. Yamagata, Gunma University). The amount of fertilizers added in 11. of enriched water were 0.3 mg. of nitrogen and 0.2 mg. of phosphorus. Photosynthetic rate of the raw water showed fairly high initial value, and the response of photosynthesis to fertilization was not so conspicuous. Marked response, however, was recognized with the sample waters from oligotrophic and mesotrophic lakes (Fig. 5). The surface water of mesotrophic Lake Yamanaka contained only about 0.01 mg./l. nitrogen and 0.002 mg./l. phosphorus in July 1956. There dominated Fragilaria sp. and Melosira sp. The photosynthetic

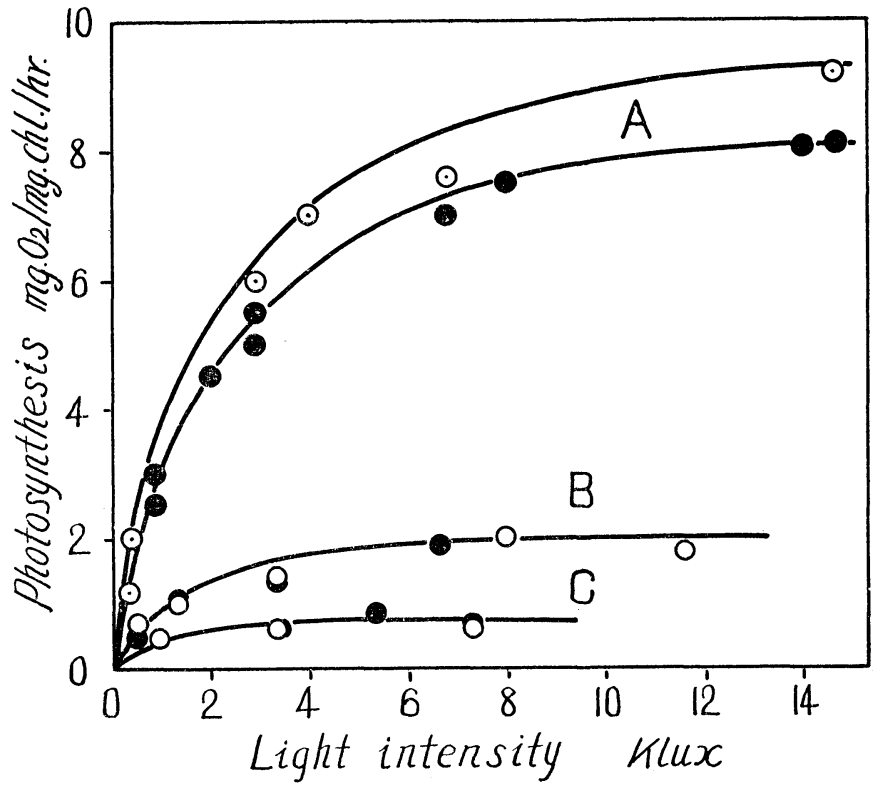

Fig. 4. Effect of fertilization with $\mathrm{NO}_{\mathrm{O}}$, and $\mathrm{PO}_{4}$ on photosynthetic rate. Curves $A$ : obtained with surface water taken from Lake Jōnuma. Curve B: obtained with water taken at $4 \mathrm{~m}$. depth of Lake Kasumigaura. Curve C: obtained with water taken at $1 \mathrm{~m}$. depth of Lake Jonuma. Filled circles show the data obtained with raw water, and open circles those with fertilized water.

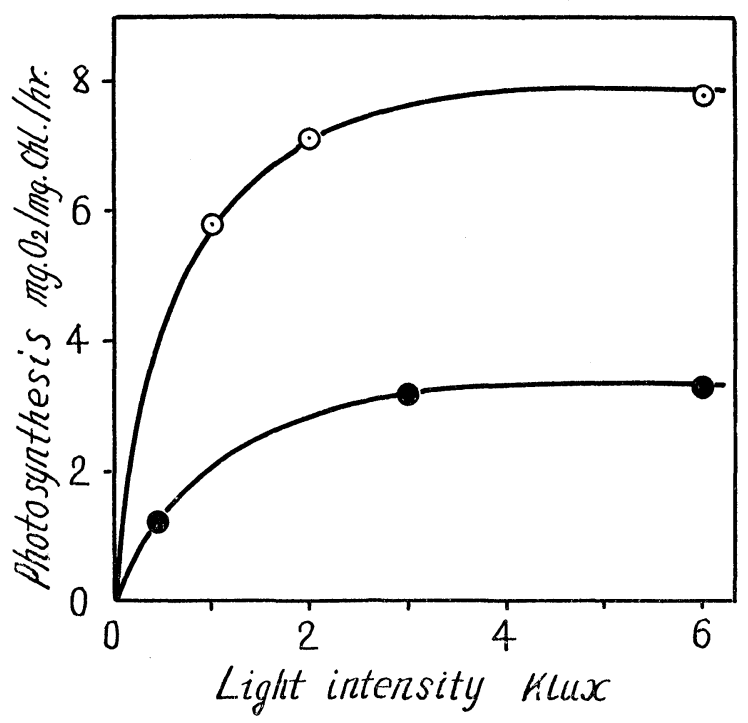

Fig. 5. Effect of fertilization on photosynthesis of phytoplankton living in surface water of mesotrophic Lake Yamanaka.

- Raw water, -(2)- enriched water. activity of phytoplankton in such raw waters was very low and its maximum was less than $4 \mathrm{mg} . / \mathrm{mg}$. chl./1. With addition of proper amount of fertilizers $\left(\mathrm{NO}_{3}-\mathrm{N}, 0.5 \mathrm{mg}\right.$. /1., $\mathrm{PO}_{4}-\mathrm{P}, 0.2 \mathrm{mg} / \mathrm{l}$.) the photosynthetic activity was promoted up to the high value which would be observed in eutrophic lakes. It may be inferred from these results that the low primary production generally measured in oligo. trophic lakes should be refered to shortage of nutrient materials in water.

Depletion of nutrients frequently appears even in eutrophic lakes, generally in summer and in autumn. 
As an example, the results obtained with samples taken from Lake Teganuma in

Table 2. Effect of nutrient salts on photoynthesis

\begin{tabular}{|c|c|c|}
\hline Fertillizer mg./1. & \multicolumn{2}{|c|}{$\begin{array}{l}\text { Photosynthesis } \\
\mathrm{O}_{2} \mathrm{mg} \cdot / 1 . / \mathrm{hr} \text {. } \\
25^{\circ} 15^{\circ}\end{array}$} \\
\hline $\begin{array}{c}\text { Raw lake water containing } \\
0.01 \mathrm{NO}_{3}-\mathrm{N} \\
\text { trace } \mathrm{PO}_{4}-\mathrm{P}\end{array}$ & 0.16 & 0.12 \\
\hline $\begin{aligned} \text { Fertilized } & \text { with } \\
0.05 & \mathrm{NO}_{3}-\mathrm{N} \\
0.50 & \mathrm{NO}_{3}-\mathrm{N}\end{aligned}$ & $\begin{array}{l}0.23 \\
0.34\end{array}$ & $\begin{array}{l}0.15 \\
0.21\end{array}$ \\
\hline 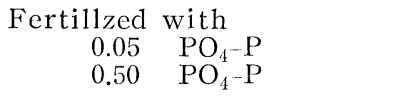 & $\begin{array}{l}0.29 \\
0.39\end{array}$ & $\overline{0.22}$ \\
\hline $\begin{aligned} \text { Fertilized } & \text { with } \\
0.50 & \mathrm{NO}_{3}-\mathrm{N} \\
0.50 & \mathrm{PO}_{4}-\mathrm{P}\end{aligned}$ & 0.45 & 0.32 \\
\hline
\end{tabular}

October are summarized in

Table 2. Autumn peak of phytoplankton population which had generally been found in many lakes, was not observed in this lake. The amount of phosphorus in the water was almost nil, and only $0.01 \mathrm{mg} . / 1$. of nitrogen was detected. In this season application of fertilizers is quite effective on photosynthesis. Same phenomena were observed also in Lake

Kasumigaura. These results may suggest that one of the most important causes for autumn reduction of the primary production in lakes is rather the depletion of nutrients in water, and not due to the deterioration of phytoplankton.

The immediate effect of fertilization on photosynthesis was not recognized in the sample taken from deeper layer of lake. Lower curve in Fig. 4 shows the result obtained with sample waters from $1 \mathrm{~m}$. depth of Lake Jōnuma and from $4 \mathrm{~m}$. depth of Kasumigaura. The nutrient concentrations in the waters just after fertilization were $0.5 \mathrm{mg}$./ $/$. of nitrogen and $0.2 \mathrm{mg}$./1. of phosphorus. In this case, the extremely low photosynthesis in the raw waters could not be recovered by fertilization. The cause is probably attributed to the deterioration of phytoplankton itself. However, it should also be taken into consideration that the phytoplankton living in feeble illumination of deeper layer sometimes is characterized by the photosynthesis of shade leaf type as measured by Gessner (1949).

\section{Effect of temperature upon photosynthesis}

The vertical diversity of temperature in trophogenous layer is not so remarkable as the decrease of light intensity with depth. Temperature factor rather seems to be important for determining the geographical and seasonal productivity (Ichimura 1954).

Experiments were done with waters collected from surface of several eutrophic lakes in every month. Tanks filled with sampled waters were incubated at various temperatures in out-of-door for 48 hours. Then, materials were filled into glass bottles and set out in water baths with various temperatures at which the sample had been incubated, with amplitude of $\pm 2^{\circ}$. Some results are indicated in Fig. 6. The productivity of water was generally increased with rising of temperature, although some of the samples which were taken in late summer or in winter did not show any sensitivity to temperature change. The results obtained with diatoms (Fragilaria, Melosira) and gree-blue algae are shown Fig. 7. The optimum tempera- 
ture was about $15^{\circ}$ in the former and $22^{\circ}-25^{\circ}$ in the latter. Diatoms showed more efficient activity than green-blue algae in low temperature range. However, the decrease of photosynthetic rate at high temperature is more noticeable in diatom than in greenblue algae. Moreover, it is interesting to notice that very high photosynthetic rate had sometimes been measured in field at about $5^{\circ}$, just after melting of ice, for example, in Asterionella formosa in Lake Harunako.

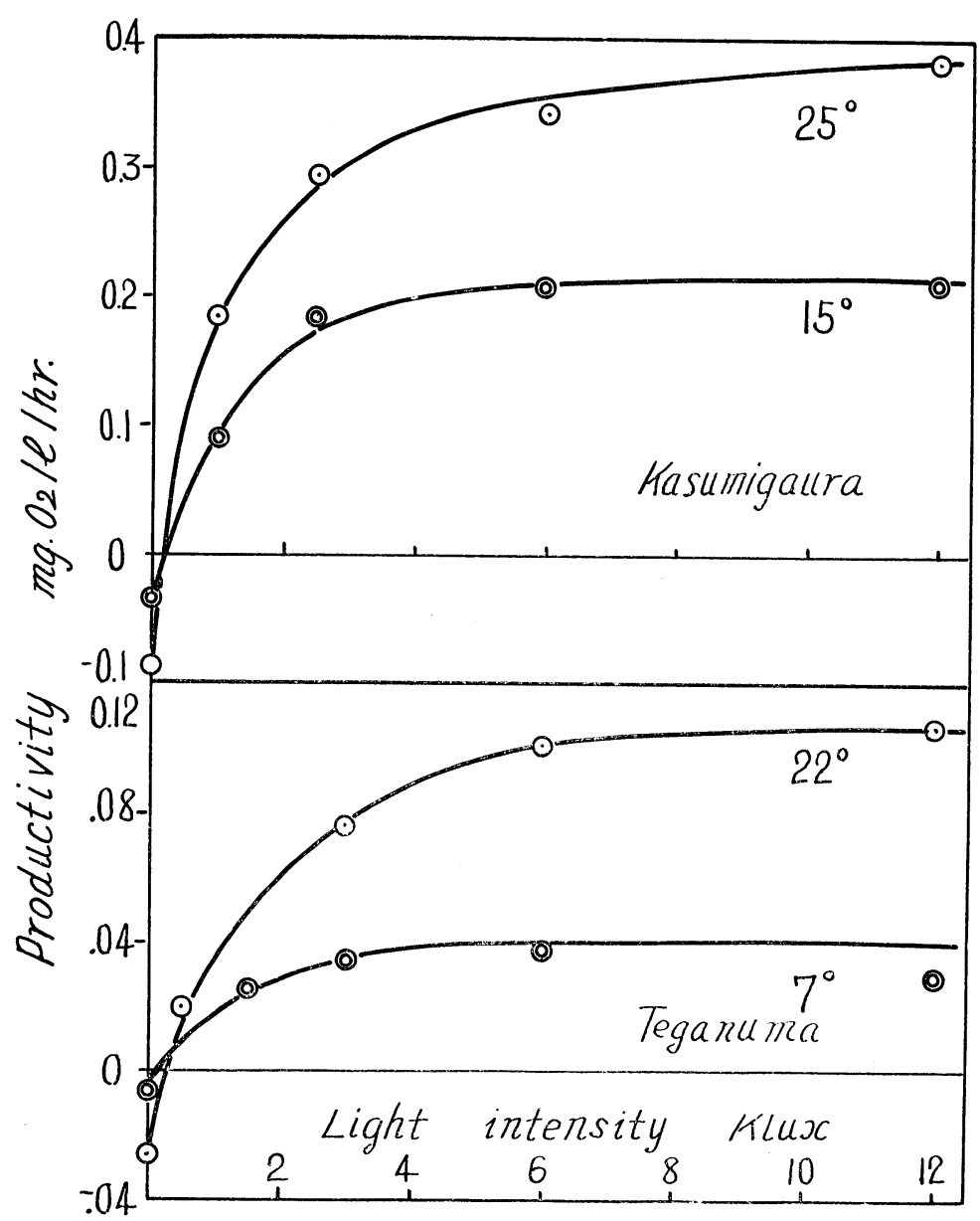

Fig. 6. Effect of temperature on productivity of surface water. Kasumigaura, Nov. 23, Teganuma, May 14.

\section{Seasonal change in potential photosynthetic activity of phytoplankton}

As shown in one of the previous papers (Ichimura 1958), the photosynthesis of phytoplankton indicates remarkable seasonal variation in the fields and variation is mainly attributable to the change of its environmental factors. However, there remains another serious problems whether phytoplankton living under severe natural conditions can keep its constant potential photosynthetic activity throughout the year. If the potential activity differs in each season, it would not be easy to deduce the primary production of a lake from simple calculation as introduced by Manning and Judy (1941), Hogetsu and Ichimura (1954), and Ryther and Yentsch (1957).

For the sake of elucidation of this problem, following experiments were carried out throughout the year at a constant temperature of $20^{\circ}$ with lake waters supplied with nutrient materials in the optimal level of $\mathrm{PO}_{4}-\mathrm{P} 0.2 \mathrm{mg} . / 1 ., \mathrm{NO}_{3}-\mathrm{N} 0.5 \mathrm{mg}$./l. and 


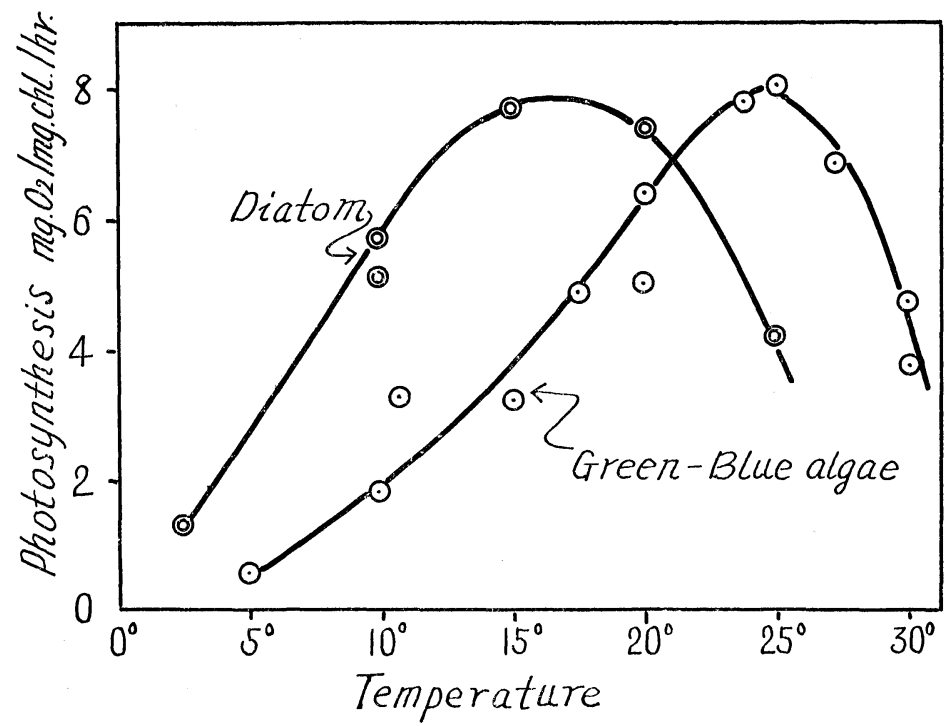

Fig. 7. Relation between photosynthetic rate and temperature measured in diatom and green.blue algae. tatol $\mathrm{CO}_{2} \quad 40 \mathrm{mg} . / \mathrm{l}$. The results obtained at light saturation are shown in Fig. 8. From the results it may be known that the potential photosynthetic activity of phytoplankton population is, as a whole, almost constant throughout the year, except for two spells in late summer and in late winter. Low photosynthetic activity in these two

spells might be attributed to the deterioration of the phytoplankton. Actually, such spells accorded with the periods when the algae constitutents were altering.

\section{Summary}

The relation of photosynthesis of natural phytoplankton to each environmental factor was dis-

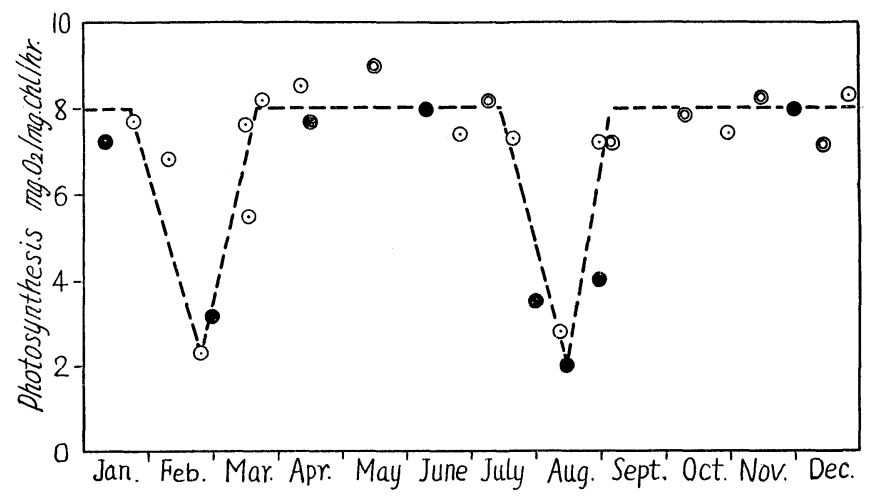

Fig. 8. Seasonal change in popential photosynthetic activity of phytoplankton of eutrophic lakes.

(a) Lake Kasumigaura, $\odot$ Lake Teganuma, Lake Nakanuma cussed in detail on the basis of laboratory experiments.

1. In eutrophic lake water, or in water enriched with nutrient salts, light saturation of photosynthesis occurred at about $15 \mathrm{klux}$. in Cyanophyceae communities, at about 10 klux. in Chlorophyceae, and at 7 klux. in Bacillariophyceae. Such light saturation, however, was found at low light intensity of about 4 klux. with phytoplankton in oligotrophic lake water.

2. The highest photosynthetic activity of phytoplankton of about $8 \mathrm{mg} . \mathrm{O}_{2} / \mathrm{chl}$. $\mathrm{mg}$./hr. was measured in natural waters of eutrophic lakes. The activity in mesotrophic lake was about $4 \mathrm{mg}$. $\mathrm{O}_{2} / \mathrm{chl} . \mathrm{mg}$. $\mathrm{hr}$. and the lowest was $2 \mathrm{mg}$. $\mathrm{O}_{2} / \mathrm{chl}$. mg./ hr. in oligotrophic lakes. 
3. The effect of supply of nutrient salts on photosynthesis of phytoplankton was not so remarkable in eutrophic lake waters as in oligotrophic ones. However, nutrient materials in water were exhausted sometimes even in eutrophic water in summer and autumn, and the deficiency in such materials would be able to limit the primary production of lakes severely.

4. Potential photosynthetic activity of phytoplankton was almost constant throughout the year, except for two spells in March and in August when heavy altering of constitutent phytoplankters were going.

The authors wish to express their cordial gratitude to Prof. M. Monsi and Prof. K. Hogetsu under whose guidance this research has been carried out. Also their thanks should be expressed to Prof. T. Miwa for his valuable suggestion and encouragement.

\section{References}

1) Edmondson, W. T., and Edmondson, Y.H., J. Mar. Res. 6: 228 (1947). 2) Gessner, F., Schweiz, Z. f. Hydrologie 11: 378 (1949). 3) Hogetsu, K., and Ichimura, S, Jap. J. Bot. 14 : 280 (1954). 4) Ichimura, S., Jap. J. Bot. $14: 269$ (1954). 5) ___, Bot. Mag. Tokyo $71: 110$ (1958). 6) - and Saijō, Y., ibid. $71: 174$ (1958). 7) Manniug, W. M., and Judy R. E., Trans. Wis. Acad. Sci., Arts Lett. 33 : 363 (1941). 8) Ryther, J. H., and Yentsch, C. S., Limno$\log y$ and Oceanography $2: 281$ (1957). 9) Yoshimura, S., Limnology (1937). 